\title{
Puerperal involution in the mare - a comparison of clinical signs and pathology
}

\author{
Katja Steiger, Franziska Kersten, Heike Aupperle, Doris Schoon and H.-A. Schoon
}

Institut für Veterinär-Pathologie, Universität Leipzig, Deutschland

\begin{abstract}
Summary
A detailed morphological and functional description of equine endometrial involution is necessary for the understanding of alterations leading to a reduced fertility rate following peripartal disturbances. A complete involution of the microcaruncles, glands and stroma by the $9^{\mathrm{h}}$ day post parturition and the return to cyclical activity is essential for an early post partal pregnancy. After normal parturition, a loss of the glandular cytokeratin-expression, the absence of laminin in the glandular basal lamina and an intraepithelial expression of vimentin occurs especially on the $3^{\text {rd }}$ and $6^{\text {th }}$ day post partum (p.p.). The expression of estrogen receptors and progesterone receptors of intact glandular epithelial cells decreases from the $3^{\text {rd }}$ to the $6^{\text {th }}$ day p.p. and increases from the $6^{\text {th }}$ to $9^{\text {th }}$ day p.p.. Decreased fertility rate in the first post-partum heats in mares with dystocia or retained placental delivery may be due to a higher incidence of periglandular fibrosis and a disturbed glandular redifferentiation, which is characterized by a delayed inset of epithelial cytokeratin-expression and an unphysiological expression of the hormone receptors Moreover, in mares with dystocia a disturbed microcaruncular involution may contribute to the decreased conception rate.
\end{abstract}

Keywords: $\quad$ equine, endometrial involution, dystocia, retentio secundinarum, endometrial biopsy

\section{Klinische Pathologie der puerperalen Involution bei der Stute}

Eine detaillierte morphologische und funktionelle Charakterisierung der equinen endometrialen Involution ist unerlässlich für das Verständnis der zu Fertilitätsstörungen führenden Alterationen. Die Fähigkeit der Stute zur frühen post-partalen Konzeption ist abhängig von einer weitgehend abgeschlossenen Involution von Mikrokarunkeln, Drüsen und Stroma bis zum 9. Tag nach der Geburt, sowie der zyklussynchronen Aktivität aller endometrialen Strukturen. Nach einer Normalgeburt treten vor allem am 6. und 9. Tag post partum (p.p.) ein Verlust der glandulären Zytokeratinexpression, das Fehlen von Laminin in der Basallamina der Drüsen sowie eine intraepitheliale Vimentinexpression auf. Die Expressionsintensität der Östrogen- und Progesteronrezeptoren nimmt physiologischerweise zwischen dem 3. und 6. Tag p.p. ab und zwischen dem 6. und 9. Tag p.p. zu. Ursachen für die erniedrigte Fertilitätsrate bei Stuten mit Schwergeburten oder verzögerter Ablösung der Plazenta sind möglicherweise eine erhöhte Inzidenz periglandulärer Fibrosen und die verlangsamte glanduläre Redifferenzierung, die sich in Form eines verzögerten Einsetzens der Zytokeratinexpression und einer unphysiologischen Expression der Hormonrezeptoren ausprägt. Die außerdem be Stuten mit Schwergeburten auftretende gestörte Involution der Mikrokarunkeln trägt wahrscheinlich zu der gestörten Konzeptionsfähigkeit bei.

Schlüsselwörter: Pferd, endometriale Involution, Schwergeburt, Retentio secundinarum, Endometriumbiopsie

\section{Introduction}

The functional and morphological characterization of the puerperal equine endometrium are of particular interest, because of the ability of the mare to conceive again in the first two weeks post partum (p.p.). Rapid restoration of the equine endometrium is therefore necessary. Puerperal endometrial morphology after normal birth (Gygax et al. 1979, Katila 1988, Katila et al. 1988), induced parturition (Bailey and Bristol 1983) and hormonal puerperal treatment (Sexton and Bristol 1985) have been described. The ultrastructure of microcaruncles from three to 96 hours after parturition have been investigated by Steven et al. (1979). All authors agree that the microcaruncular involution is mostly completed by the $9^{\text {th }}$ day p.p., but it still remains unclear as to whether the vacuolated appearance of the endometrial glands is a sign of degeneration or secretion (Katila 1988). To date, immunohistochemical studies of the normal equine puerperal endometrium are not available.

Although the fertility of mares with dystocia and retentio secundinarum in the foal heat is lower than after normal birth, little is known about the morphological aspects of the equine endometrial involution during peripartal disturbances (Belz and Glatzel 1995, Kersten 2000). Higher incidences of epithelial damages occur after still births (Steven et al. 1979) and after induced parturition (Bailey and Bristol 1983). Belz (1994) describes stromal bleedings and endometrial atrophy caused by retentio secundinarum.

The aim of this study was to characterize the puerperal endometrium of mares using histopathological and immunohistochemical methods and to describe some aspects of the pathogenesis of the lowered fertility rate following a disturbed partus or puerperium.

\section{Material and methods}

Gestation time, course of parturition (tab. 1) and the puerperium of 47 mares (aged 3 to 19 years, mean 8 years) (tab. 2) from a stud-farm in the North of Germany were observed. A placental delivery of more than three hours after parturition was defined as a placental retaining in contrast to a retentio secundinarum that takes more than 6 hours after parturition (Sobiraj 1996). The mares with a retained placenta were treated with 50 IE Oxytocin/1 I saline solution intra-venously 
Tab. 1: Classification of the course of parturition

Charakterisierung der Gruppen anhand des Geburtsverlaufes

\begin{tabular}{|l|c|c|c|}
\hline \multicolumn{1}{|c|}{ Group 1a } & Group 1b & Group 2 & Group 3 \\
\hline \multicolumn{1}{|c|}{ Normal birth } & Premature birth & Dystocia & Retained placenta \\
\hline $\begin{array}{l}\text { finished after 30 minutes } \\
\text { no corrections, no strong drawing or } \\
\begin{array}{l}\text { medication necessary } \\
\text { delivery of the placenta completed after the } \\
\text { first 3 hours p.p. }\end{array}\end{array}$ & $\begin{array}{l}\text { gestational time }<330 \\
\text { days but } \\
\text { normal birth }\end{array}$ & $\begin{array}{l}\text { duration of birth }>30 \\
\text { minutes and/or } \\
\text { strong drawing or } \\
\text { medication }\end{array}$ & $\begin{array}{l}\text { undisturbed birth but } \\
\text { delivery of the placenta } \\
\text { after }>3 \text { hours p.p. }\end{array}$ \\
\hline
\end{tabular}

three hours after parturition and with a uterine lavage once daily for the next three days. The placenta fetalis was investigated macroscopically and histologically (for further details see Kersten 2000). The clinically unremarkable mares of all groups ( $\mathrm{n}=28$ ) were inseminated in the foal heat and 20 mares were treated with prostaglandins to induce the second heat. All nonpregnant mares were inseminated in each heat until the end of the breeding season except for five mares that were not assigned for breeding any more. The fertility of the mares was determined by the length of the period between the date of birth and the following conception. The mares were examined on the $3^{\text {rd }}, 6^{\text {th }}$ and $9^{\text {th }}$ day after parturition by vaginoscopy and rectal palpation of the genital tract. Endometrial biopsies were also collected.

The endometrial biopsies were fixed in formalin, embedded in paraplast and stained with HE. In samples from 22 mares with normal parturition and puerperium $(n=7)$, premature birth $(n=5)$, dystocia $(n=5)$ and a retained placental delivery $(n=5)$ the expression of the intermediate filaments, desmin and vimentin, the microfilament $\alpha$-smooth muscle actin, the factor VIII-related antigen, the basal lamina-components laminin and collagen IV, the proliferation marker Ki 67-antigen and the estrogen- (ER) and progesterone-receptors (PR) were determined by immunohistochemistry. The expression patterns of estrogenand progesterone-receptors were ascertained by an immunoreactive score (IRS) (Özgen et al. 1997).

\section{Results}

Age of the mares and course of parturition and puerperium (tab. 2)

The mares with premature births are significantly younger $(p<0.01)$ than those of the other groups.

\section{Rectal palpation}

A rapid involution of the uterine size, as observed in all mares with a normal birth, occurs in $40 \%$ of the mares with dystocia and in $35 \%$ with retained placentae. On the $9^{\text {th }}$ day p.p. asymmetrical diameters of the uterus horns occur in $11.5 \%$ of group 1. A higher incidence of asymmetry is observed in the mares with dystocia (57.1\%) and with delayed placental delivery (42.9\%). The uterine contractility is moderate to high on the $6^{\text {th }}$ and $9^{\text {th }}$ day after parturition in the mares of group 1 and 3 , whilst a decrease in mares with dystocia is observed. None of the mares with peripartal disturbances had ovulated until the $9^{\text {th }}$ day after parturition.

\section{Endometrial biopsies}

Morphological and immunohistochemical findings in groups la and $7 \mathrm{~b}$ (normal birth at term and preterm)

The morphological findings in groups $1 \mathrm{a}$ and $1 \mathrm{~b}$ (normal birth at term and preterm) are described as one since neither morphological nor immunohistochemical differences are apparent.

The intact luminal epithelium is cuboidal with basal nuclei, which are partially lifted from the basal lamina by basal vacuols especially on the $6^{\text {th }}$ day p.p.. The epithelial basal lamina beneath these cells is interrupted. Luminal epithelium defects decrease between the $3^{\text {rd }}$ and $9^{\text {th }}$ day p.p.. Sporadically neutrophilic granulocytes infiltrate the luminal epithelium.

On the $3^{\text {rd }}$ day p.p. the epithelial cells in the apical center parts of the microcaruncles show a luminal and basal expression of cytokeratin in $80.7 \%$ of the mares (fig. 1). In some of these cells, degenerative changes with signs of karyorrhexis and karyolysis and some apoptotic bodies are present. Epithelial cells detaching from their basal lamina are visible in the intermediate area of the microcaruncles (fig. 1). Contrary to all proliferating small capillaries of the peripheral areas, only very few capillaries in the central area of the microcaruncels show an expression of factor VIII-related antigen. On the $6^{\text {th }}$ and $9^{\text {th }}$ day p.p. epithelial cells can no longer be detected within the microcaruncles. On the $6^{\text {th }}$ day p.p. there is a moderate edema within the microcaruncles. Some homogenous eosinophilic material is visible in the H.-E. stain. It consists of moderate amounts of collagen IV in the apical parts and laminin in the deep parts of the microcaruncles. The

Tab. 2: Correlation between age and course of birth

Zusammenhang zwischen Alter und Geburtsverlauf der Stuten

\begin{tabular}{|c|c|c|c|c|c|}
\hline \multicolumn{2}{|c|}{ Age in years } & $\begin{array}{c}\text { Normal } \\
\text { birth } \\
(n=17)\end{array}$ & $\begin{array}{c}\text { Premature } \\
\text { birth } \\
(n=9)\end{array}$ & $\begin{array}{c}\text { Dystocia } \\
(n=7)\end{array}$ & $\begin{array}{c}\text { Retained } \\
\text { placenta } \\
(n=14)\end{array}$ \\
\hline $3-6$ & $n=21$ & $n=10$ & $n=6$ & $n=2$ & $n=3$ \\
\hline $7-10$ & $n=15$ & $n=2$ & $n=3$ & $n=3$ & $n=7$ \\
\hline $11-19$ & $n=11$ & $n=5$ & $n=0$ & $n=2$ & $n=4$ \\
\hline mean age & 8.0 & 7.18 & 5.3 & 8.4 & 9.5 \\
\hline
\end{tabular}


edema and the eosinophilic material are reduced on the $9^{\text {th }}$ day p.p.fig. 2). The recapillarisation of the microcaruncles is mostly completed on the $9^{\text {th }}$ day p.p.. The cellular infiltration of the microcaruncles changes during the puerperium: On the $3^{\text {rd }}$ day p.p. a slight to moderate diffuse lymphocytic infiltration occurs. Additionally, in $42.3 \%$ of these mares a few neutrophilic granulocytes are visible. The inflammatory cells disappear on the $9^{\text {th }}$ day p.p.. Macrophages occur exclusively as siderocytes in all mares on the $6^{\text {th }}$ day p.p. in moderate amounts, increasing to high amounts on the $9^{\text {th }}$ day p.p.. Only one mare shows a slight infiltration with eosinophilic granulocytes on the $9^{\text {th }}$ day p.p.. The number of endometrial glands increases in all mares from the $3^{\text {rd }}$ to the $9^{\text {th }}$ day p.p..

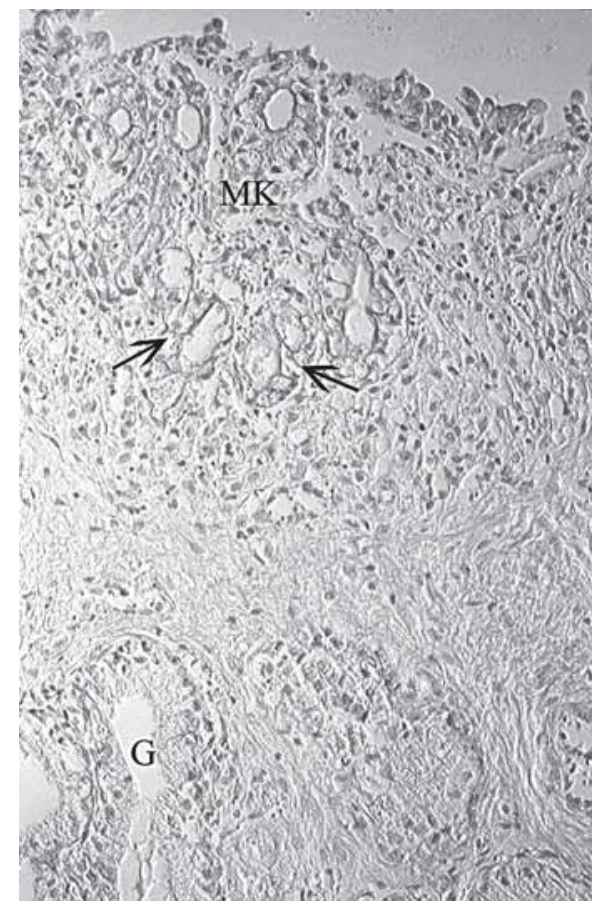

Fig. 1: Cytokeratin expression on the $3^{\text {rd }}$ day p.p. in a 10-year-old mare after normal birth: An expression of cytokeratin in epithelial cells (arrows) is only visible in the central parts of the microcaruncles (MK). Some microcaruncular cells are detached from the basal lamina. No cytokeratin-expression can be detected in the endometrial glands (G), which are characterized by numerous subnuclear vacuoles, that lift the nucleus from the basal lamina. (Immunohistochemistry, cytokeratin, Normarski-interference-contrast, magnification 62.5x)

Zytokeratinexpression im Endometrium einer 10;ährigen Stute am 3. Tag nach normaler Geburt: Nur in den zentralen Bereichen der Mikrokarunkel (MK) sind am 3 Tag nach einer Normalgeburt Zytokeratin exprimierende Mikrokarunkelepithelzellen (Pfeile) nachweisbar. Einzelne dieser Zellen sind von der Basallamina abgelöst. Die endometrialen Drüsen (G), in denen zahlreiche, den Kern von der Basallamina abhebene subnukleäre Vakuolen auftreten, exprimieren kein Zyłokeratin. (Immunhistologie, Zyłokeratin, Normarski-InterferenzKontrast, Gerätevergrößerung 62,5x)

On the $3^{\text {rd }}$ day p.p., the glandular lumina contain a few neutrophilic granulocytes and some cellular debris. Some secretory granules occur in the apical areas of the cytoplasm of the columnar glandular epithelia. In all mares numerous perinuclear vacuoles lift the nucleus from the basal lamina (fig. 1) and sporadic apoptotic bodies are visible. Only a very slight diffuse expression of cytokeratin in some glandular cells with perinuclear vacuolisation is present (fig. 1); instead an unphysiological perinuclear expression of vimentin occurs in $61.5 \%$ of these vacuolated cells. The basal lamina of the glands is often discontinuous and no laminin or collagen IV is detectable within the basal lamina. On the $6^{\text {th }}$ day p.p. differences between the morphology of the upper and the deeper lying glands are observed. The epithelial cells of the glandular ducts have round to oval, basally located hyperchromatic nuclei. They show a slight expression of cytokeratin. In $42.3 \%$ of the mares a perinuclear expression of vimentin is detected within these glands. Basal vacuoles can be demonstrated only in the epithelial cells of the deeper glands. There is absence of or only very slight expression of cytokeratin within these cells, but in $80.8 \%$ of the mares a moderate perinuclear expression of vimentin is visible. A high mitotic activity occurs in these glands, detected by the expression of the Ki 67-antigen. No laminin can be found in the basal lamina of these glands. On the $9^{\text {th }}$ day after parturition the epithelia of the glandular ducts and the non-vacuolated glands are columnar with round to oval hyperchromatic nuclei and some mitoses are observed. There is a slight to moderate expression of cytokeratin in $85.7 \%$ of the mares and a continuous basal lamina can be demonstrated by the presence of laminin in the non-vacuolated glands of all mares. Only a few of the deeper glands still have some vacuoles. In contrast to the findings on the previous days, these cells show a slight expression of cytokeratin and in 60\% of the mares laminin is present in the basal lamina of these glands. There is absence of or only very slight intraepithelial expression of vimentin in $85.7 \%$ of the mares even in the vacuolated glands.

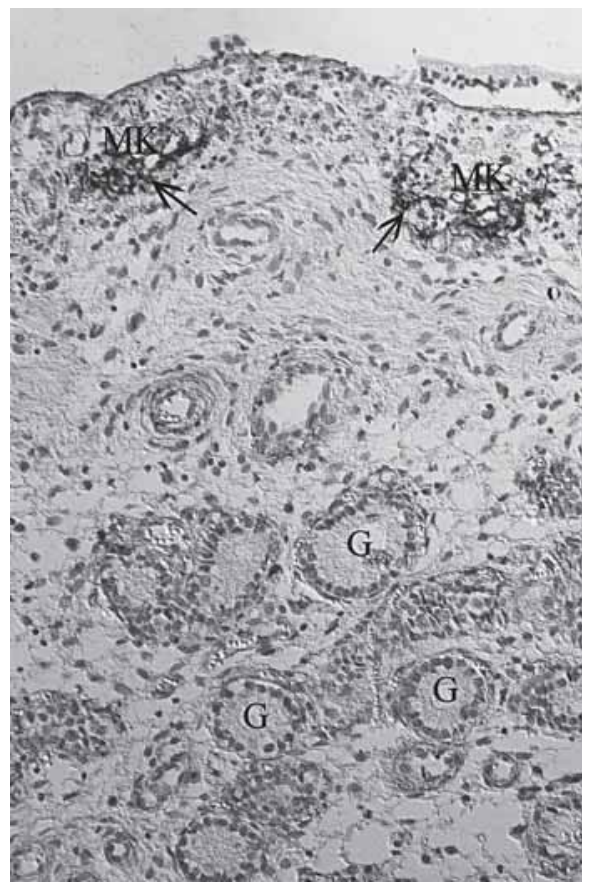

Fig. 2: Expression of collagen IV in the endometrium of a 12-year-old mare on the $9^{\text {th }}$ day after normal birth: The remnants of the microcaruncles (MK) are still visible as accumulated subepithelial parts of their basal lamina (arrows) detectable by the occurrence of collagen IV. No collagen IV can be demonstrated in the glandular (G) basal lamina. (Immunohistochemistry, collagen IV, Normarski-interference-contrast, mag. 62.5x)

Nachweis von Kollagen IV im Endometrium einer 12jährigen Stute am 9. Tag nach normaler Geburt: Die Mikrokarunkel (MK) sind anhand der subepithelial akkumulierten Reste ihrer Basallamina (Pfeile) am 9. Tag p.p. darstellbar. Die glanduläre (G) Basallamina enthält kein Kollagen IV. (Immunhistologie, Kollagen IV, Normarski-Interferenz-Kontrast, Gerätevergrößerung 62,5x) 
All stromal cells show a moderate vimentin-expression. In the absence of collagen IV a slight intracellular expression of laminin is detected in several stromal cells. The mild to moderate stromal infiltration by neutrophilic granulocytes on the $3^{\text {rd }}$ day p.p. decreases to a very slight infiltration on the $9^{\text {th }}$ day p.p.. The number of lymphocytes occurring in the stroma increases from slight to moderate. Some eosinophilic granulocytes are observed on the $6^{\text {th }}$ and $9^{\text {th }}$ day p.p. in $19.2 \%$ and $23.1 \%$ of the mares respectively. $A$ high number of siderocytes are located in the periglandular stroma.

Morphological and immunohistochemical findings in group 2 (dystocia)

Following dystocia the number of mares with a loss of more than $50 \%$ of the luminal epithelium is significantly higher than in mares after normal birth on the $6^{\text {th }}$ and $9^{\text {th }}$ day p.p. $(p<0,05)$. In comparison to the mares of group 1, 66.6\% of the mares with dystocia have an intact epithelial lining in the whole microcaruncles on the $3^{\text {rd }}$ day p.p.. Two mares still show epithelial remnants of some microcaruncles on the $9^{\text {th }}$ day p.p.(fig. 3). These residues are characterized by dilated microcaruncular lumina with a flat epithelium and a distinct neutrophilic and lymphocytic infiltration (fig. 3). Additionally, $80 \%$ of the mares demonstrate a moderate amount of laminin in the microcaruncles in contrast to the findings in group 1. In $80 \%$ of the mares the recapillarisation of the microcaruncles is not completed on the $9^{\text {th }}$ day p.p.. Moderate to high numbers of neutrophils occur in most of the mares on the $3^{\text {rd }}$ and $6^{\text {th }}$ day p.p.. On the $9^{\text {th }}$ day p.p. infiltration decreases to slight or

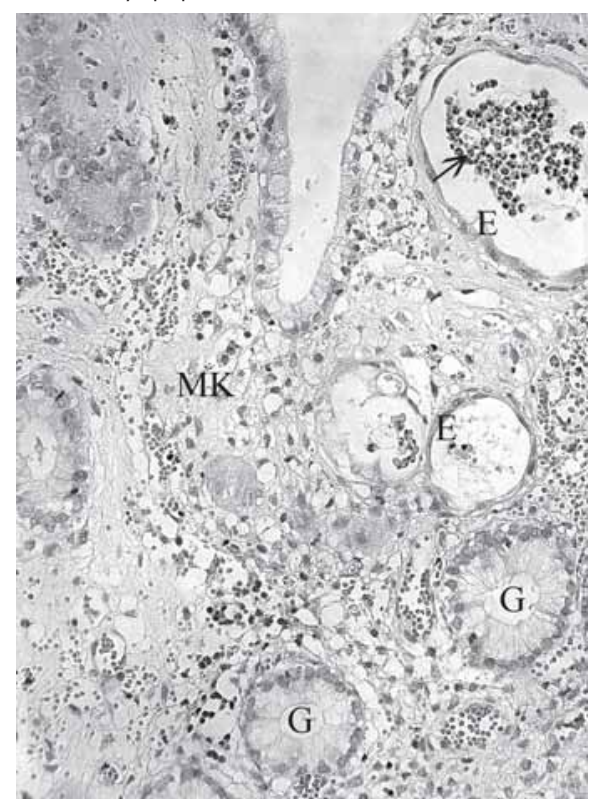

Fig. 3: Endometrial biopsy of an 8-year-old mare on the $9^{\text {th }}$ day after dystocia: Dilated epithelial microcaruncles $(E)$ are still detectable. The microcaruncles (MK) are infiltrated especially by neutrophilic granulocytes (arrow). The endometrial glands $(G)$ still show signs of secretory activity. (H.-E., magnification 62.5x)

Endometriumbiopsie einer 8 jährigen Stute am 9. Tag nach einer Schwergeburt: Die Lumina der Mikrokarunkeln (MK) sind immer noch epithelial (E) ausgekleidet und deutlich dilatiert. Die Mikrokarunkel werden vorwiegend durch neutrophile Granulozyten (Pfeil) infiltriert. Die endometrialen Drüsen zeigen immer noch Anzeichen einer sekretorischen Aktivität. (H.-E. Färbung, Gerätevergrößerung 62,5x) moderate amounts. Compared to the mares of group 1, no differences concerning the lymphocytic microcaruncular infiltration are observed.

On the $3^{\text {rd }}$ day p.p. the morphology of the glandular epithelia corresponds to the findings in mares after a normal birth but the return to normal activity is delayed. On the $6^{\text {th }}$ day p.p. more than $50 \%$ and on the $9^{\text {th }}$ day p.p. more than $30 \%$ of the glands are still vacuolated. The cytokeratin expression in these vacuolated epithelia is diminished in $80 \%$ of the mares compared to the findings in group 1. The intraepithelial perinuclear expression of vimentin is slight to moderate in the deeper as well as in the vacuolated glands on the $9^{\text {th }}$ day p.p.. In most glands the basal lamina still remains nearly invisible even on the $9^{\text {th }}$ day p.p..

The stromal infiltration by lymphocytes corresponds to that described in group 1. Although a moderate to severe neutrophilic infiltration occurs on the $3^{\text {rd }}$ day p.p. the differences to group 1 diminish until the $9^{\text {th }}$ day after parturition. One mare shows some eosinophilic granulocytes infiltrating the stratum compactum on the $6^{\text {th }}$ and $9^{\text {th }}$ day p.p..

Morphological and immunohistological findings in group 3 (retained delivery of the placenta)

After a retained delivery of the placenta the number of mares with a loss of more than $50 \%$ of the luminal epithelium is significantly higher than in mares after normal birth on the $6^{\text {th }}$ and $9^{\text {th }}$ day p.p. $(p<0.05)$.

There are no morphological signs of a delayed involution process of the microcaruncles in these mares as found in group 2 . The microcaruncels are infiltrated by a moderate amount of neutrophilic granulocytes on the $3^{\text {rd }}$ day p.p., but the degree of infiltration decreases on the $6^{\text {th }}$ day p.p. and the findings on the $9^{\text {th }}$ day p.p. correspond to those in group 1. Compared to the mares of group 1 no differences concerning the lymphocytic microcaruncular infiltration are observed. A slight infiltration of eosinophilic granulocytes occurs in three mares.

The return to normal glandular activity is delayed after a retained placental delivery. On the $6^{\text {th }}$ day and $9^{\text {th }}$ day p.p. more than $50 \%$ and about $40 \%$ of the glands respectively demonstrate a vacuolated epithelium, whilst all the deeper glands have a vacuolated appearance. The cytokeratin expression in vacuolated epithelial cells is very low in $80 \%$ of the mares compared to the findings in group 1. But no increased coexpression of vimentin is observed in their glandular epithelia. In all mares the glandular basal lamina is nearly invisible in more than $50 \%$ of glands even on the $9^{\text {th }}$ day p.p.

The stromal lymphocytic infiltration corresponds to that found in group 1. A moderate to severe neutrophilic infiltration is present on the $3^{\text {rd }}$ day p.p., and although the amount decreases during the time investigated, still $35.1 \%$ of the mares in group 3 show slight to moderate stromal infiltration of neutrophils on the $9^{\text {th }}$ day p.p. Eosinophilic granulocytes occur in one mare on the $3^{\text {rd }}$ day p.p. and in three mares on the $6^{\text {th }}$ and $9^{\text {th }}$ day p.p..

Periglandular fibrosis (fig. 4)

$61.5 \%$ of the mares in group 1 show a mild or moderate periglandular fibrosis on the $3^{\text {rd }}$ day p.p.. On the $6^{\text {th }}$ as well as 
on the $9^{\text {th }}$ day p.p. no signs of endometrosis are apparent in one mare that demonstrated a mild endometrosis on the earlier days investigated (fig. 4). But in two mares the degree of the endometrosis increases from slight to moderate between the $6^{\text {th }}$ and the $9^{\text {th }}$ day p.p.. Fibrotic nests occur in $18.7 \%$ of the mares with endometrosis on the $3^{\text {rd }}$, in $26.6 \%$ on the $6^{\text {th }}$ and in $28.8 \%$ on the $9^{\text {th }}$ day p.p. In more than $85 \%$ of the mares the endometrosis consists of inactive stromal cells. A destructive fibrosis cannot be observed.

Following dystocia the percentage of mares showing a periglandular fibrosis is higher on the $9^{\text {th }}$ day p.p. compared to the mares in group 1 (fig. 4). On the $3^{\text {rd }}$ day p.p. the endometrosis of $66.6 \%$ of the mares is mild, and moderate on the $6^{\text {th }}$ and on the $9^{\text {th }}$ day p.p. in $50 \%$ of the mares. Fibrotic nests occur on the $6^{\text {th }}$ (50\% of the mares with endometrosis) and on the $9^{\text {th }}(66.6 \%$ of the mares with endometrosis) day p.p..

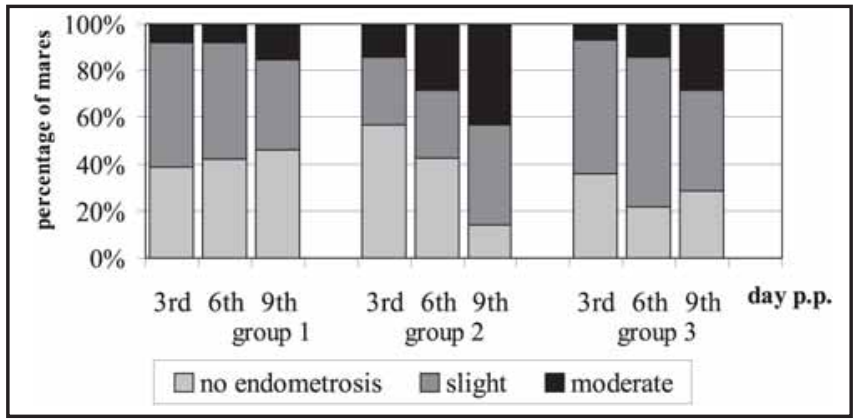

Fig. 4: Degree of endometrial fibrosis correlated to the course of birth

Auftreten und Grad endometrialer Fibrosen in Korrelation mit dem Geburtsverlauf

After the delivery of a retained placenta, the number of mares showing a periglandular fibrosis on the $9^{\text {th }}$ day p.p. is higher than after a normal birth (fig. 4). In 18.2\% of the mares the endometrosis is moderate on the $6^{\text {th }}$ day p.p. and moderate or severe in $45.5 \%$ on the $9^{\text {th }}$ day p.p.. Fibrotic nests occur in $18.2 \%$ on the $6^{\text {th }}$ and in $27.3 \%$ of the mares with endometrosis on the $9^{\text {th }}$ day p.p..

Expression of estrogen- and progesterone-receptors

In group 1 the expression of ER (fig. 5) and PR in the glandular ducts and morphologically normal glands decreases between the $3^{\text {rd }}$ and $6^{\text {th }}$ day p.p. and increases again on the $9^{\text {th }}$ day p.p.. The IRS of ER (fig. 5) and PR in the vacuolated glands and the stromal cells increases continuously from the $3^{\text {rd }}$ to the $9^{\text {th }}$ day p.p.

A higher expression of ER and PR on the $6^{\text {th }}$ day p.p. in the apical glands together with a continuously increasing expression in the basal glands is observed in $60 \%$ of the mares with premature births.

The expression of ER and PR in group 2 and group 3 differs from the physiological course in all epithelia (fig. 6) and no correlation between the IRS of ER and PR can be detected in these mares except of a very slight expression of both hormonereceptors on the $3^{\text {rd }}$ day p.p. in the ducts, apical and basal glands of $80 \%$ of the mares.

The expression of ER and PR in the stromal cells remains low in all mares of group 2 and group 3 during the whole investigated time.

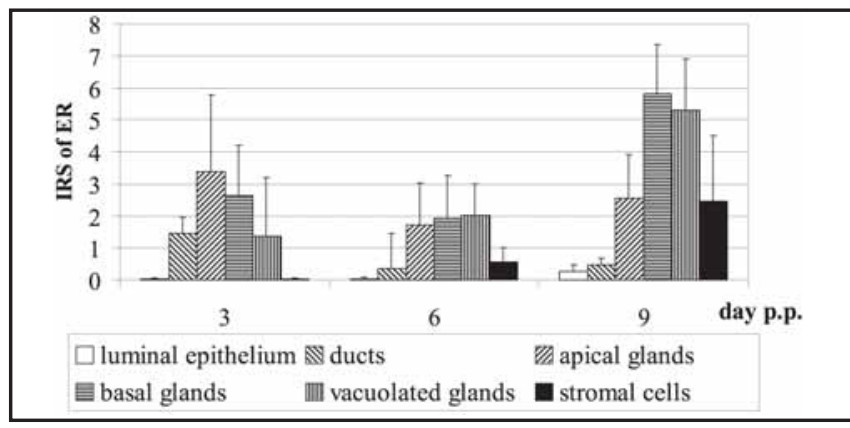

Fig. 5: Expression (IRS) of estrogenreceptors (ER) after normal parturition (group 1)

Expression (IRS) der Östrogenrezeptoren (ER) nach normaler Geburt (Gruppe 1)

Fertility in the foal heat and in later breedings (fig. 7)

In each group one mare did not become pregnant at the end of the breeding season. But the number of heats needed to achieve a new pregnancy is increased in the mares of group 2 and 3 (fig. 7).

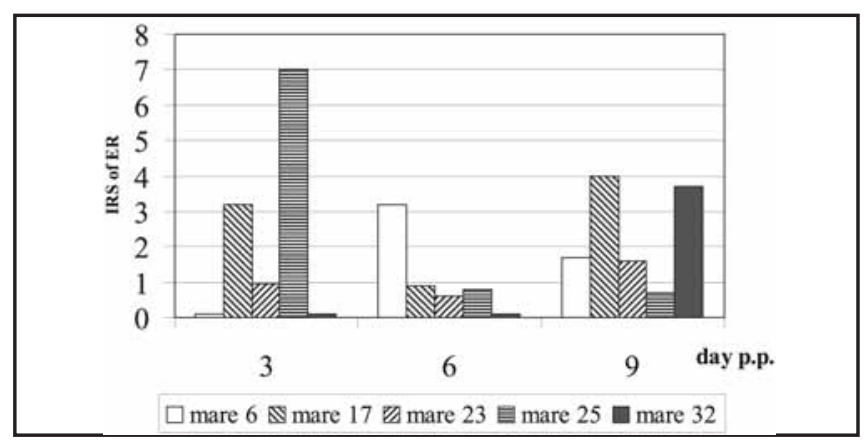

Fig. 6: Course of ER-expression (IRS) of apical glands in 5 mares with dystocia (group 2)

Östrogenrezeptorexpression (IRS) in apikalen Drüsenquerschnitten bei 5 Stuten mit Schwergeburt (Gruppe 2)

\section{Discussion}

The endometrial involution in combination with an early postpartal ovarian activity, is necessary for the mare's ability to conceive again soon after a parturition. The process of detaching of the epithelial microcaruncular cells from their basal lamina begins in the periphery of the microcaruncles. The fact that no macrophages are observed within these areas leads to the suggestion that the cells of the microcaruncles are mostly peeled off into the lumen. Additionally, the areas of the former microcaruncles are recapillarised from the periphery.

According to the findings of Katila (1988) and Belz (1994), the involution of the equine microcaruncles is completed on the $9^{\text {th }}$ day p.p. after normal parturition. Our investigations confirm a normal microcaruncular involution also in mares with a delayed placental delivery. In contrast, a disturbed regression of these structures after dystocia was demonstrated. This differs from the findings of Belz and Glatzel (1995), who describe the microcaruncular involution as independent of the course of birth. Our findings may be due to the lower post partal uterine contractility observed in these mares. This is probably caused by the delayed post partal decrease of progesterone-levels after dystocia and retentio secundinarum as observed by Vande- 
plassche et al. (1983) in combination with a myometrial weariness after dystocia. The hypoxia of the microcaruncular epithelia may be diminished because of the absence of uterine contractions, which may disturb the microcaruncular involution in these mares. Further ultrastructural studies are needed for a detailed characterization of the microcaruncles following peripartal disturbances.

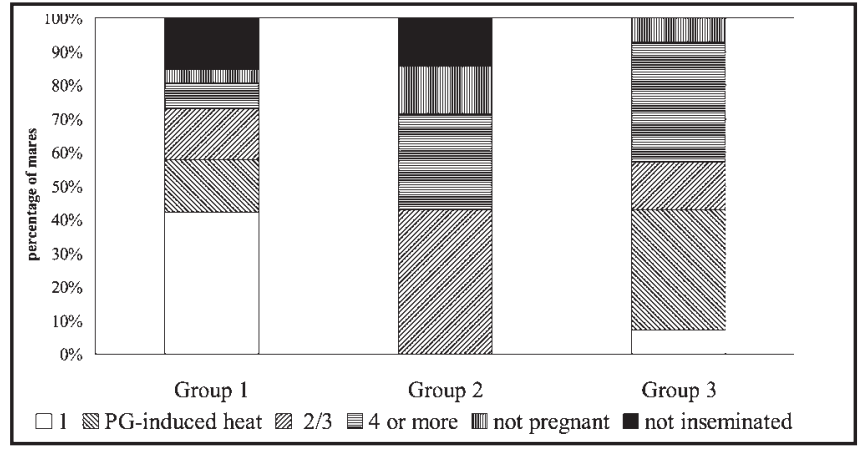

Fig. 7: Number of heats needed to achieve a new pregnancy Anzahl Rossen bis zur erneuten Trächtigkeit

According to the findings of Belz (1994) no microcaruncular alterations occur after a retained delivery of the placenta. Although higher incidences of epithelial defects in the placenta fetalis were observed by Kersten (2000), the delayed detaching of the placental structures does not seem to cause similar lesions in the microcaruncles. The fact that the placental retention was defined as a three hour delay of the delivery of the placenta in our study may be one more reason for the absence of microcaruncular alterations in these mares in contrast to findings after manual placental removal observed by Steven et al. (1979). The physiological differentiation of the glandular epithelia is demonstrated by the recurrence of the cytokeratin-expression, a continuous expression of laminin in the basal lamina and the characteristic course of ER and PR expression. According to the findings of Aupperle (1997) an intraepithelial vimentin-expression is correlated with a high mitotic activity within these cells. The physiological glandular differentiation as well as the proliferative activity are signs of the normal endometrial cycle, which is essential for a conception.

Bracher et al. (1997) describe an increased glandular function in the late stages of pregnancy in mares suffering from severe endometrial fibrosis and fibrotic nests diagnosed in biopsies collected before breeding. In our study endometrosis occurs in more than $50 \%$ of the mares with normal parturition.

Contrary to the findings in the microcaruncles, alterations occur in the endometrial glands both after dystocia and retentio secundinarum. These lesions are characterized by an atypical expression of the hormone receptors, a higher incidence of vacuolated glandular epithelia on the $6^{\text {th }}$ and $9^{\text {th }}$ day p.p. and a delayed inset of cytokeratin-expression in these cells. The reason for the disturbed glandular differentiation may be a hormonal dysregulation occurring in these mares (Vandeplassche et al. 1983, Belz 1994).

It may be concluded that the microcaruncular alterations contribute to the decreased fertility in the first post-partum heats in mares after dystocia. Furthermore a complete glandular regeneration seems to be important for a successful new pregnancy. The increased incidence of endometrosis in mares with peripartal disturbances may also contribute to the decreased post-partal fertility of these mares.

Endometrial biopsies are an important aid for determining the glandular condition and, in combination with the clinical findings, for estimating the probability of a successful insemination.

\section{Literature}

Aupperle, H. (1997): Immunhistologische Untersuchungen am Endometrium der Stute. Leipzig, Veterinärmedizinische Fakultät, Dissertation

Bailey, J.V. and F.M. Bristol (1983): Uterine involution in the mare after induced parturition. Am. J. Vet. Res. 44, 793-797

Belz, J.P. (1994): Klinische, mikrobiologische, histologische und hormonanalytische Untersuchungen im Puerperium der Stute im Hinblick auf die folgenden Rossen. Berlin, FB Veterinärmedizin, Dissertation

Belz, J.P. and P.S. Glatzel (1995): Fertility in mares after a disturbed as well as an undisturbed puerperium. Significance of histological and cytological examinations of the uterus. Tierärztl. Prax. 23, 267-272

Bracher, V., C. Gerstenberg and W.R. Allen (1997): Der Einfluss von Endometrose (degenerativer Endometriumserkrankungen) auf Fruchtbarkeit, Plazentation und fötale Entwicklung beim Pferd. Pferdeheilkunde 13, 465-473

Katila, $T$ (1988): Histology of the post partum equine uterus as determined by endometrial biopsies. Acta Vet. Scand. 29, 173-180

Katila, T., E. Koskinen, M. Oijala and P. Parviainen (1988): Evaluation of the post-partum mare in relation to foal heat breeding 2. Uterine swabbing and biopsies. J. Vet. Med. Ass. 35, 331-339

Kersten, F. (2000): Klinische, histologische und zytologische Untersuchungen im Puerperium der Stute sowie ein Beitrag zur Kyematopathologie unter besonderer Berücksichtigung der Placenta fetalis. Leipzig, Veterinärmedizinische Fakultät, Dissertation

Özgen, S., K. Rasch, G. Kropp, H.-A. Schoon, H. Aupperle, H. Sieme and E. Klug (1997): Aetiopathogenesis and therapy of equine hydromucometra: preliminary data. Pferdeheilkunde 13, 533-536

Sexton, P.E. and F.M. Bristol (1985): Uterine involution in mares treated with progesteron and oestradiol-17ß. J. Am. Vet. Med. Ass. 186, 252-256

Sobiraj, A. (1996): Retentio secundinarum und andere postpartale Zwischenfälle bei der Stute. Prakt. Tierarzt 77, 67-69

Steven, D.H., L.B. Jeffcott, K.A. Mallon, S.W. Ricketts, P.D. Rossdale and C.A. Samuel (1979): Ultrastructural studies of the equine uterus and placenta following parturition. J. Reprod. Fert., Suppl. 27, 579-586

Vandeplassche, M., J. Spincemaille, R. Bouters, P. Bonte und M. Coryn (1983): Observations on involution and puerperal endometritis in mares. Irish Vet. J. 37, 126-132

\section{Dr. Katja Steiger}

Institut für Veterinär-Pathologie

Universität Leipzig

An den Tierkliniken 33

04103 Leipzig

Tel.: (0341) 9738270

Fax: (0341) 9738299

e-mail:Steiger@rz.uni-leipzig.de 